This item was submitted to Loughborough's Research Repository by the author.

Items in Figshare are protected by copyright, with all rights reserved, unless otherwise indicated.

\title{
Conceptualizing lived religious citizenship: a case-study of Christian and Muslim women in Norway and the United Kingdom
}

PLEASE CITE THE PUBLISHED VERSION

http://dx.doi.org/10.1080/13621025.2015.1049979

\section{PUBLISHER}

(C) Taylor \& Francis

\section{VERSION}

AM (Accepted Manuscript)

\section{PUBLISHER STATEMENT}

This work is made available according to the conditions of the Creative Commons Attribution-NonCommercialNoDerivatives 4.0 International (CC BY-NC-ND 4.0) licence. Full details of this licence are available at: https://creativecommons.org/licenses/by-nc-nd/4.0/

\section{LICENCE}

CC BY-NC-ND 4.0

\section{REPOSITORY RECORD}

Nyhagen, Line. 2019. "Conceptualizing Lived Religious Citizenship: A Case-study of Christian and Muslim Women in Norway and the United Kingdom". figshare. https://hdl.handle.net/2134/17154. 
Conceptualizing Lived Religious Citizenship: A Case-Study of Christian and

Muslim Women in Norway and the United Kingdom

Forthcoming in Citizenship Studies, Vol. 19, No. 6-7, 2015.

Line Nyhagen

Department of Social Sciences

Loughborough University

Loughborough

LE11 3TU

L.Nyhagen@lboro.ac.uk

Acknowledgments

The author wishes to thank Esmeranda Manful (UK) and Beatrice Halsaa and Hanna Helseth (Norway) who, as part of the Work Package 4, Strand 2 team of the FEMCIT project, conducted the interviews with religious women. She also wishes to thank the editors of the journal and the anonymous reviewers for their constructive and very useful comments and suggestions. Preliminary project findings were reported in a working paper submitted to the European Union (see Nyhagen Predelli et al. 2010).

Funding

The research on which this manuscript is based, was funded by the European Union $6^{\text {th }}$ Framework Programme (project number 028746). 


\section{Abstract}

The concept of 'religious citizenship' is increasingly being used by scholars, but there are few attempts at defining it. This article argues that rights-based definitions giving primacy to status and rights are too narrow, and that feminist approaches to citizenship foregrounding identity, belonging and participation, as well as an ethics of care, provide a more comprehensive understanding of how religious women understand and experience their own 'religious citizenship'. Findings from interviews with Christian and Muslim women in Oslo and Leicester suggest a close relationship between religious women's faith and practice ('lived religion') and their 'lived citizenship'. However, gender inequalities and status differences between majority and minority religions produce challenges to rights-based approaches to religious citizenship.

\section{Key words}

Citizenship; religious citizenship; lived religion; gender and religion;, women and Islam, women and Christianity.

\section{Introduction}

Religious actors have recently become more accepted as legitimate stakeholders in contemporary public life, as many European governments increasingly rely on faith-based organizations to provide educational and welfare services (Bäckström and Davie 2010). The role of religion in the public sphere is, however, intensely debated (Casanova 1994; Weithman 2002; Habermas 2006; Dillon 2010; Turner 2012; Beaman 2013). While religion continues to play a 
significant role in many people's everyday life, meaning constructions and personal identities (McGuire 2008), potential conflicts and contradictions between religious freedom, religious accommodation and human rights are being debated (Rosenblum 2000; Spinner-Halev 2000; Loenen and Goldsmith 2007), as well as conflicts between religious freedom and gender equality (Okin 1999; Sunstein 1999; Skjeie 2006).

A less visible but notable development in recent scholarship is the increasing use of the term 'religious citizenship' (e.g., Beaman 2013; Permoser and Rosenberger 2009; Ryder 2008; Levitt 2004; Yip 2003). Few scholars, however, offer any precise definition of what religious citizenship entails. As a consequence, empirical studies tend to use the term 'religious citizenship' as an 'imposed' analytical category from a top-down perspective, rather than examining how individuals and groups may understand it in thought and practice. Scholars have also noted that there is a lack of comparative empirical studies of how citizenship is lived, especially 'with regard to citizens' own understanding of citizenship's meaning '(Lister et al., 2007, 168).

This article argues that rights-based approaches to religious citizenship are too narrow. They silence inequalities based on gender and different statuses accorded to majority and minority religions, and overlook the importance of identity, belonging, participation, and care towards others, in lived citizenship practices. Applying a bottom-up, qualitative research approach, this article examines how Christian and Muslim women in Norway and the United Kingdom (UK) practice religious citizenship, their views on the term, and opportunities and constraints they experience as religious women. The article develops a critical perspective on the concept of 'religious citizenship' by linking it to the 
concept of 'lived religion' (McGuire 2008), to issues of gender inequality, to differences between religious majority and minority groups, and to notions of identity, belonging, participation, and care. In particular, the article shows that religious women may accept gender inequalities as an inherent part of their own religious identity and lived citizenship practice, and argues that such a stance poses a direct challenge to the notion that religious citizenship must be based on equal rights. The article also demonstrates that 'religious citizenship' has multiple meanings among the interviewed religious women, thus making it difficult to offer an alternative, precise definition of the term. Instead, a multifaceted approach is required which acknowledges that rights, status, identities, participation, belonging and care are important dimensions of religious citizenship as lived practice.

\section{Citizenship, multiculturalism, religion and gender}

Scholars who examine political and social aspects of religion are increasingly invoking the term 'citizenship' in debates about religious rights, religious freedom, and political claims-making rooted in religious convictions (e.g., Spinner-Halev 2000; Rosenblum 2000). The idea that religion and citizenship are connected is not new; indeed, many states offer preferential treatment to specific religions (e.g., Church of England bishops hold unelected seats in the UK parliament), and full citizenship rights are sometimes exclusively conferred upon members of particular religions (e.g., the public practice of minority religions may be outlawed, as in Saudi Arabia) (see Fox 2008). The term 'religious citizenship' is, however, of more recent coinage; its usage gaining momentum alongside the development in citizenship theory towards differentiation between 
political, social, economic, multicultural, gendered, sexual, intimate, ecological and technological dimensions of citizenship (see Isin and Wood 1999; Lister et al. 2007). Feminist scholars in particular have also advanced the idea that citizenship is not only about status and rights, but also about participation, identities and belonging, or 'lived practice' in people's everyday lives (Lister 2003; Lister et al. 2007). Moreover, citizenship is 'multi-layered' (Yuval-Davis 1999), as people's experiences of citizenship are mediated by their multiple identities and loyalties to families, groups and wider communities. Through building on such feminist approaches to citizenship, and examining how religious women understand and experience citizenship in their everyday life, this article argues that rights-based approaches do not capture the full complexity of women's religious citizenship.

The feminist move towards conceptualising citizenship in terms of lived practice is paralleled by developments in the sociology of religion, which emphasise religion as lived or practiced in everyday life. American sociologists McGuire (2008) and Ammerman (2007) both suggest that religion in contemporary society cannot be fully understood through perspectives that centre on formal religious organisations and 'institutionally defined beliefs and practices' (McGuire 2008, 12). Instead, the concept of lived religion shifts the focus onto 'the actual experience of religious persons' as individuals and as participants in wider social contexts (ibid.). Top-down approaches to citizenship and to religion that centre on formal aspects of rights, statuses, institutions and doctrines are thus being complemented by bottom-up approaches that focus on how people understand, practice and negotiate citizenship in everyday life (Lister et al. 
2007) and that are 'grounded in the everyday ways modern persons relate to the things they experience as religious or spiritual' (Ammerman 2007, 5).

Theorists of multiculturalism, gender and feminism (e.g., Eisenberg and SpinnerHalev 2005; Okin 1999; Phillips 2010) highlight discrepancies between a rhetoric of inclusion and actual practices of exclusion along intersecting inequalities such as gender, ethnicity, and religion. Specific practices among national, cultural, and religious minorities have, however, variously been emphasized as needing protection (to preserve traditions) and political recognition (assigning particular rights to such minorities), or as needing to be challenged, contested, or even abolished (e.g., Okin 1999). Some scholars have also called for gender equality to be assigned a higher or equal priority to the principle of religious freedom (Skjeie 2006; Sunstein 1999). The question of state intervention in what some perceive as 'internal religious matters' has thus been raised: should gender equality be imposed on religious organisations, or is it better if it emerges from within?

Answers to this question rely, at least in part, on whether or not religious organisations are viewed as private or as public entities. It can be argued, however, that in combining private religious beliefs, civil society activism, and public deliberation and intervention, religious organisations represent a contested borderland where the practice and negotiation of citizenship status, rights, identities, participation and belonging may become especially acute. In relation to gendered (and sexual) aspects of citizenship, the religious field, in its different formations across various beliefs and practices, presents a test case for the inclusion or exclusion of women (and of sexual minorities) in the broader understanding of citizenship promoted by feminist scholars. Moreover, women's 
religious identities, beliefs and practices may pose challenges to both rightsbased and feminist conceptualisations of citizenship. For example, scholars such as Mahmood (2005), Göle and Billaud (2012) highlight that women’s agency can emerge from religious forms of piety that accept, rather than reject, gender inequalities. Religious women themselves must therefore be asked about whether they experience their lived citizenship within religious communities as empowering or restricting in relation to their gender.

\section{'Religious citizenship'}

Despite an increasing use of the term 'religious citizenship' by academics (e.g., Beaman 2013; Permoser and Rosenberger 2009; Ryder 2008; Levitt 2004; Yip 2003), there are few attempts at offering precise definitions of what it means. A recent instance is that of Beaman (2013), who discusses 'obligatory religious citizenship'. While Beaman suggests that a 'responsibilized citizen' is increasingly being framed as a religious citizen (ibid., 145), she does not offer a definition of the term. Another case is Levitt (2008), who uses the concepts 'religious citizenship' and 'religious global citizenship' to draw attention to transnational migrants' civic engagement via religious organizations. However, Levitt does not give a more precise understanding of what she means by these terms. In contrast to these two examples where 'religious citizenship' is used quite loosely. Permoser and Rosenberger (2009) provide an attempt at delineating what 'religious citizenship' consists of by suggesting it includes individual rights, group rights and 'corporate rights'. Discussing the governance of religious diversity in Austria, with a focus on Muslim immigrants, Permoser and Rosenberger (ibid., 151) argue that 'the increasing number of rights derived 
from religious membership amount to a form of "religious citizenship" that transcends nationality and therefore increases the rights of Muslim immigrants'. These two authors foreground three types of rights: the universal right to freedom of religion; group-differentiated rights (related to Islam as a minority religion; e.g., rights to wear religious clothing, praying at work, religious holidays, etc.); and what they call 'corporate rights' allocated to a specific organisation (the Islamic Faith Community Organisation in Austria) which the state recognizes and cooperates with as the assumed representative of all Muslims in Austria (ibid.). Hudson (2003) also forwards a predominantly rights-based approach to religious citizenship. Nevertheless, Hudson suggests that religious citizenship can be defined in multiple ways, including a nation-state definition where 'religious citizenship is the citizenship that your nation-state allows you to exercise in religious matters' (ibid., 426) and a civil society definition, where 'religious citizenship is the citizenship which citizens exercise as religious persons in the civic sphere' (ibid.). Hudson also talks about religious citizenship in terms of the rights of persons, and says that religious citizenship can be approached via existing legal documents including national and international law on religion and belief. Finally, Hudson suggests that individuals may obtain religious citizenship through 'adopting specific discursive positions' linked to particular religions, such as by calling themselves 'Christians or Buddhist or secularists' (ibid., 427). Important challenges can be directed towards the rights-based approaches to religious citizenship offered by these authors: What is the importance of gender, and of majority/minority religious status, for the practising of religious 
citizenship? Gender inequalities remain a serious obstacle to equal religious citizenship, and religion-based discrimination of women continues to perpetuate patriarchal gender relations within families, communities, states and globally (Bayes and Tohidi 2001). In its liberal version, a rights-based approach to defining religious citizenship neglects the issue of gender discrimination and the ways in which women are differently situated within their religious communities. Moreover, a rights-based approach is too narrow because it ignores dimensions that religious women themselves deem important. In their lived practice of religious citizenship, women may prioritise belonging and participation related to religious identities, groups and communities, rather than gender equality in the form of equal rights for women and men. As such, gendered forms of religious citizenship practice may support the feminist move to include identities, belonging and participation as important dimensions of lived citizenship, but they may also challenge feminist ideals of citizenship as gender equal. Moreover, despite in many instances being denied equal status and rights with men, religious women (and also sexual minorities) have been able to circumvent and challenge discriminatory rules and conventions, and to carve out independent roles and dignified practices for themselves. At other times, women have accepted a subordinate status in relation to men as part of religious frameworks that assigns meaningful roles to women as wives, mothers and carers (Davidman 1993). Whether religious identities, participation and belonging provide barriers or resources for women's citizenship practices must therefore be investigated in specific, historical, socio-political contexts. Reflection is also required on the relationship between a religious majority and religious minorities, as well as between religious and non-religious (or secular) 
beliefs. In European countries, Christianity is privileged either because of historical, political, cultural, or social, reasons (Fox 2008); a privilege that has 'so far mainly gone unrecognized' by 'those who have been born and raised in Europe in a traditional European style" (Van den Brink 2007, 214). In turn, religious majority or minority status may intersect with other forms of inequality, including those pertaining to religion and gender.

\section{Research contexts and methods}

This study forms part of a larger, comparative research project, which determined the selection of countries for in-depth case studies (see Nyhagen Predelli and Halsaa 2012). Historically, both Norway and the UK have a Christian majority church, while other religions have mainly been established through post-World War 2 immigration. Fox (2008) describes Norway as having an active state religion (the Lutheran Church), and the UK as having a historical or cultural state religion (the Anglican Church in England and Wales). In both countries, Christianity enjoys a privileged position in relation to the extant political systems, and it is the largest religion in terms of followers. Islam forms the second largest religion in both Norway and England due to immigration. Both countries have enshrined the principle of religious freedom in government legislation, and religious minorities are basically free to operate as they wish. Issues related to multiculturalism, religion, integration and social cohesion are, however, much debated, and there are tensions between the state, majority society and religious minorities in both contexts. In Norway, for example, the building of Muslim places of worship and the wearing of headscarves and veils by Muslim women and girls are highly politicised issues. In the UK, relations 
between the state and Muslim communities became increasingly tense and politicized after the terrorist attacks in London in July 2005. The wearing of religious symbols and headgear is also controversial in the UK (Kilic 2008). The initial idea was to recruit women from religious organisations formed specifically for women in the two countries. However, while the UK has a variety of religious women's organisations at national and local levels that represent a wide range of faith traditions, Norway's religious women's organisations at the national level are predominantly Christian. Only at the local level in Norway can we speak of religious pluralism in the landscape of religious women's associations. In order to achieve comparable interview data, women were recruited from religious congregations including churches and mosques. Indepth, qualitative interviews were conducted with a total of forty Christian and Muslim women who partake in such religious organisations in two multicultural locations: that of Leicestershire in the East Midlands region of England (UK), and that of Oslo, Norway's capital city. Leicestershire county includes the city of Leicester, which is one of the most multicultural cities in England, while Oslo is the most multicultural city in Norway.

Departing from the substantial distinction between Christianity as the majority religion and Islam as a minority religion in both country contexts, the study adopted a four-dimensional recruitment strategy which included dominant Christian churches (in the form of state churches or churches privileged by the state) and lesser privileged Christian churches (in the form of a 'free church' Christian denomination), as well as Muslim mosques that represented, respectively, either the largest Muslim immigrant group or a smaller Muslim immigrant population in each of the two countries. Dominant Christian churches 
were easily identifiable, and a large church was chosen in each country-specific location (a Lutheran church in Oslo, Norway and an Anglican church in Leicester, England). As Pentecostalism is the 'fastest growing group of churches within Christianity today' (Anderson 2004:1), Pentecostal churches (Assembly of God in both countries) were selected as the Christian denomination with no formal ties to the state. Pakistanis form the largest Muslim immigrant groups in both Norway and the UK, and are part of the wider community of Sunni Islam, which accounts for about eighty per cent of the world's adherents to Islam (Esposito 1998). We also wanted to reach Shia-Muslims, as Shia-Islam represents about twenty per cent of Muslim believers worldwide (ibid.). Whilst it was relatively easy to recruit women from a Shia mosque in Oslo, this turned out to be more difficult in Leicester, where the recruited Shia women attended Sunni rather than Shia mosques. This was due to the availability of designated spaces for women in some Sunni mosques and the lack of such spaces in some Shia mosques. In each country, ten Christian women (5 from the dominant church and five from the less privileged church) and ten Muslim women (5 from the Sunni tradition and five from the Shia tradition) were interviewed. Some of the Muslim interviewees had immigrated to Norway or the UK. The ages of participants ranged from 20 to 73 . The interviews, which were conducted in $2009^{1}$, were recorded, transcribed, and analysed thematically. In both Norway and the UK, participants would be unfamiliar with the scholarly term 'religious citizenship'. The term 'citizenship' also has different connotations in each country. In the UK, government and schools promote a

\footnotetext{
${ }^{1}$ The time-lag between data collection and writing is due to the length of the overall research project.
} 
broad understanding of 'citizenship' as including status, rights, duties, loyalty, belonging and active participation (see Kiwan 2007). In Norway, the term 'statsborgerskap' (state citizenship) covers legal aspects of citizenship, while 'samfunnsborgerskap' (community citizenship), and 'medborgerskap' (fellow citizenship) cover social aspects such as identity, loyalty, belonging, trust and participation (Brochmann 2002, 56-60). The Norwegian government uses the term medborgerskap to promote the active participation of citizens in society. Interviewees in the UK were asked if it made sense for them to talk about 'citizenship' as linked with religion, while in Norway, interviewees were prompted that medborgerskap can include societal participation before being asked whether 'religious citizenship' (religiøst medborgerskap) made sense to them. As stated before, there is little research on what citizens (as opposed to governments and scholars) understand by 'citizenship' and its related terms (Lister et al. 2007, 168). This article discusses evidence that religious women citizens in Norway and the UK understand citizenship in the wider sense promoted by the two respective governments and shows that they foreground issues of identity, belonging, participation and care, rather than status, rights and duties.

\section{Findings}

The findings section, which is divided in three parts, discusses how the interviewed religious women talk about and practice citizenship and religion in their everyday lives. The first section explores the participants' understanding of citizenship more generally and of a 'good citizen' in particular. It demonstrates broad support among the interviewees for an approach to citizenship which 
foregrounds identities, participation and belonging. The second section analyses the women's understanding of 'religious citizenship'. It shows that 'lived religion' is deeply intertwined with 'lived citizenship' for the participants, and that religious citizenship also invokes an ethics of care towards others which is embedded in the women's religious identities. Furthermore, it reveals that some interviewees view religious citizenship as inclusive of all religious believers as well as of non-believers, and that others view religion as being 'over and beyond' citizenship matters. The third section examines religion as a resource or barrier to citizenship as practice. It shows how gender inequalities, and also differences relating to religious majority/minority status, pose a challenge to rights-based approaches to religious citizenship. It also highlights how religious women's lived citizenship practices may challenge feminist notions of gender equality and thus further question a rights-based approach to citizenship.

\section{Understandings of citizenship}

The interviewed Christian and Muslim women in both countries forwarded very similar understandings when asked 'what does citizenship mean to you?' The classic understanding of citizenship as an individual's status was advanced by very few participants who associated citizenship with having a passport, with the right to live in a country, and to move freely across borders. Some also mentioned rights and duties as part of citizenship, such as the right to vote and the duty to respect the law. A majority of the interviewees moved beyond a rights-based approach to citizenship in their answers by advancing a multidimensional understanding, emphasizing collective and participatory aspects of citizenship. They conceptualised citizenship as playing an active role in the 
community, which in turn would benefit society as a whole: "[it] is about participating in society, playing an active role, and perhaps being a volunteer of some sort, respecting the law" (UK Pentecostal). Active participation included taking part in political processes, engaging in community groups, and being friendly and caring towards one's neighbours: "I think about being together with my neighbours and those who live around me. That is to be a citizen [medborger]. And to have a good relationship with one's neighbours, to be able to chat and to have a cup of coffee together. Go on a walk together. That is what I think being a citizen is all about" (Norwegian Pentecostal). Many participants talked about belonging as part of citizenship, thus mirroring feminist conceptualizations of citizenship as multi-dimensional and inclusive of participation and belonging (Lister 2003):

"Citizenship, the very fact that I belong to this community, I belong to this country, more particularly I look on it that I belong to this community, am a member of this community, and therefore the responsibilities, the privileges but also the responsibilities that kind of come with that, as a member of this community. So I think that is what it means, citizenship, belonging to this place" (UK Anglican).

In terms of belonging, most participants (including those with immigrant backgrounds) talked about citizenship in relation to their own local community or to the country in which they live. Regardless of their nationality and religious faith, the interviewees emphasized a sense of belonging and feeling at home in a community, thus indicating that citizenship involves emotional ties to a place (Yuval-Davis 2006). The 'community' most often had a local dimension, in the 
form of belonging to a neighbourhood, a particular mosque or congregation. A few participants also described a feeling of belonging to two countries - the one they were born in, and the one they live in, while some talked about citizenship as being part of a wider, global community.

The initial question about what citizenship means was an open one, and interviewees were therefore encouraged to talk about what they immediately associated with the term. Across the sample of forty interviewees from both countries, only a few mentioned aspects of their religion or faith as related to citizenship without being prompted. Among those who did, both Christian and Muslim participants noted that all humans are equal before God, regardless of their nationality, race, gender or religious faith. Some Muslim participants also said they experience challenges related to how they are perceived by the overall society and how much they 'belong'. As only a few participants initially linked citizenship with religion, this topic is dealt with more in-depth below.. When the interviewees were asked what they view as 'a good citizen', the answers largely mirrored their earlier responses to the broader question about what citizenship means to them. Again, most answers were complex and included more than one aspect. Contributing to society through volunteering was a dominant theme, along with 'being there for your neighbours' and more general notions of tolerance, respect, love and care towards others. Being a lawabiding citizen, respecting the society's rules and the rights of others were muchmentioned aspects of being a good citizen. What emerged from the interviews was a keen sense of citizenship as being part of a bigger whole, of relating in positive, loving, caring, tolerant and respectful ways to people in the community, of contributing to a good society through compassion and volunteering, and 
leading a life conforming to societal rules and regulations. The interviewed women thus understand and experience citizenship as a multi-layered (YuvalDavis 1999); as a phenomenon that includes participation and belonging as well as ethical notions about how people should behave towards each other. Rightsbased approaches fail to capture this complexity of religious women's lived citizenship.

\section{Religious citizenship}

When asked specifically whether it made sense for them to talk about citizenship in relation to religion, the majority of interviewees, across the different faiths and the two countries, affirmed a linkage between citizenship and religion by suggesting that their faith provides guidance on how to be a good citizen. To be 'a good citizen', 'a good Christian' and 'a good Muslim' was regarded as one and the same thing; they were deeply intertwined and inseparable. Being a good follower of the Christian and Muslim faiths included showing love and care, respect and tolerance towards other people. An ethics of care (see Tronto 2005), rooted in religious conviction yet transcending religious difference, thus emerged from the interviews as a significant dimension of lived religious citizenship. Both Christian and Muslim interviewees saw their own religion as providing instructions and guidance on how to act as a good citizen. A UK Christian participant, for example, stated that the Bible instructs Christians to be 'responsible citizens': "[...] it is part of being a Christian that as well as obviously believing in God you should be equally responsible citizens"' (UK Anglican). Similarly, A UK Shia participant noted that Islam provides its followers with guidelines that cover working, studying, bringing up children, and other areas of "private life". 
Some of the Christian participants linked citizenship to being part of a larger, Christian community, encompassing various traditions and denominations. They thus forwarded an ecumenical approach centring on the unity of Christians, and also underscored their experience of citizenship as multi-layered through membership of local, national and global collectives (Yuval-Davis 1999). For example, a Norwegian Pentecostal noted how, when travelling, she feels welcomed in churches abroad, while a Norwegian Lutheran used the term 'Christian citizenship' to denote unity and equality between followers of the Christian faith. Other interviewees, both Christian and Muslim, from both countries, forwarded a wider understanding of all religions as relevant to citizenship, as suggested by a Norwegian Lutheran; “When I hear that concept [religious citizenship], it encompasses all religions" and by a Norwegian Pentecostal; "most religions are about taking care of people around you". Treating each other well, independent of one's religious belief, was seen as important by Muslim and Christian participants in both countries, who also linked equality between humans to their equality before God. For example, a UK Sunni participant said that "[...] when it comes to citizenship, we are all servants of God", thus proposing that a common faith in God, across different religions, produces a fundamental equality between humans. Similarly, a UK Christian participant forwarded the notion that citizenship means equality between all humans: “... it [citizenship] is all about linking to my life and just treating everybody the same. Jesus Christ said that; treating everybody the same. Jesus Christ said it is about treating everybody equally, regardless of gender, race" (UK Pentecostal). The interviewees thus indicate that an ethics of tolerance, respect and care towards others is a significant dimension of religious citizenship. These findings lend 
support to the claim that rights-based approaches to religious citizenship are too narrow.

A few interviewees also included secular people in their overall notion of citizenship and equality. For example, a Norwegian Shia who thought that all religions have 'the same ethics and morals' talked about all people being equal, regardless of their religion, and included atheists or non-believers in her view of a good society where people live in peace and tolerance: "So I think that in a society we are all of us living together; that is a religious citizenship. Even if you are not religious, right?" Similarly, a Norwegian Sunni specifically mentioned respect and tolerance for each other's religious beliefs as well as the beliefs of "those without a religion". Some interviewees thus acknowledged not only the accommodation of different religious faiths, but also of non-religious or secular people, as important aspects of 'religious citizenship'. They thus suggested that the term ' religious citizenship' can be inclusive of a plurality of religious belief and non-belief, as it invoked a general ethical imperative of 'good behaviour' whose validity transcends, yet may be rooted in, particular religious beliefs. Although many research participants perceived connections between their own faith and religious practice (lived religion) and citizenship practice (lived citizenship), a few conceived of citizenship as first and foremost a secular term. They considered religion to be a matter above and beyond the issue of citizenship. For example, a UK Anglican saw citizenship as linked to secular society and to being a member or citizen of a country. A UK Pentecostal made a distinction between secular and religious forms of citizenship, in that formal citizenship of the UK has "to be earned" by immigrants coming to the country, “whereas with Christianity I believe you don't have to earn it, you just have to ask 
forgiveness and believe in God". This interviewee underscored that everyone is equal before God and that religious citizenship only requires a personal conviction or faith. 'Religious citizenship' is thus open to all who want it, while formal, legal citizenship status of a particular nation-state is conditional upon birth-right or other non-inclusive criteria. Several Muslim interviewees in particular conceived of citizenship as secular and in contrast to religion, which may be linked to Islam being a minority religion in both country contexts, as well as to the commonality between all Muslim believers (the 'Ummah') regardless of their nationality. Secular notions of citizenship forwarded by Muslim participants included the right to live in a country, a feeling of belonging to a country, and to actively participate in society. One UK Sunni stated that she is equally committed to her religion and to her (national) citizenship, but viewed them as separate and hoped she would not be made to choose between loyalty to her religion and to her country. Such views were echoed by a UK Shia who distinguished between citizenship as the right to live in a country, and her religion, Islam, which instructs her to live by the rules of whatever country she is living in. These interviewees thus suggested that religion is a matter over and beyond the issue of citizenship. Another UK Sunni, who also associated citizenship with a person's formal, legal status and not with religion, thought it would be a mistake to relate citizenship to religious belief. In her view, citizenship involves legal status differentiation and therefore inequality, while religious faith transcends status differentiation and invokes a form of equality among believers. She observed that people adhere to different religions, that the intensity of people's religious convictions differs, and that faiths have religious leaders as well as followers. This interviewee thought that if citizenship has to do 
with status differentiation, then it cannot be transferred to the complex phenomenon of religious belief:

"[...] in religion I don't think you can make the citizenship, because you have got so many different believers and the different faiths and the different levels [...]. So again those are thee different levels, and what citizenship are you going to give them, low class, middle class, higher class. So in religion I don't think citizenship makes any difference, you know".

As discussed earlier, however, most interviewees thought that it makes sense to talk about 'religious citizenship'. They made connections between being 'a good Christian' or 'a good Muslim' and being 'a good citizen', which involved respect, tolerance, love and care for others. Although rooted in religious convictions, these values transcended religious faiths in that they applied to followers of other religions and also to non-religious people. The views forwarded by the interviewees suggest that rights-based approaches to citizenship must be complemented with perspectives that emphasize identities, participation, belonging, and an ethics of care, as central to lived citizenship.

Religion as resource and barrier to lived citizenship In terms of their understanding of what citizenship means, what constitutes a good citizen, and the relationship between religion and citizenship, there were no notable differences in terms of the faith tradition the interviewed women belonged to, or which country they inhabited. When the participants were asked about their experiences of barriers, discrimination or privilege in relation to 
their faith, however, there were some pronounced differences across religious traditions and countries. Generally, both Christian and Muslim interviewees identified barriers to their lived citizenship in terms of discrimination they have experienced either within their own religious communities or within society at large. These barriers were perceived as linked to their religion, to their gender, or both. Importantly, some but not all gender inequalities within their own religious communities were talked about as producing hindrances to women's participation. For example, while it was perceived as problematic by Christian interviewees when women are not allowed to take on certain church positions of religious authority (e.g., bishops in the Church of England; elders in the Pentecostal church) ${ }^{2}$, Muslim interviewees did not perceive it as a problem that women cannot take on the role of Imam within mosques. This section first examines views on religion as resource and barrier to citizenship among Christian (Lutheran, Anglican and Pentecostal) women in Norway and the UK, before turning to the views imparted by Muslim (Sunni and Shia) women in the two countries.

Pentecostal interviewees in both countries talked about limitations to women's roles in the church as problematic, in that women cannot (in the UK congregation) or have only recently been formally allowed to (in the Norwegian congregation) take on the role of 'elders' within the church. They also noted that women speaking and preaching is a contentious issue across Pentecostal churches. Some Pentecostal interviewees suggested that churches are male led and dominated because of tradition, and that men have been using religion "to

\footnotetext{
2 The Church of England changed its rules in 2014 and the first woman bishop was appointed in December that year.
} 
control women and trying to use the Bible to justify that" (UK Pentecostal). Literal readings of the Bible were mentioned as having supported male domination in positions of religious authority. The interviewed Pentecostals were all positive about women increasingly coming into leadership positions in the church. Several participants observed that significant changes have taken place, as women used to be required to wear hats, were not allowed as preachers or as elders, and were expected to submit to men's decisions. Despite positive changes, however, interviewees noted that the Pentecostal movement was still dominated by men, and that many men still hold traditional gender views. Changes in formal rights and opportunities for women had thus still not been embraced entirely by the church, and the interviewed women experienced barriers to gender equal citizenship within the Pentecostal movement. While both UK and Norwegian Pentecostals talked about traditional gender relations within the church itself as contested, some of the UK Pentecostal participants also talked about traditional gendered practices in the home as a problem, such as the expectation by husbands that their wives should do the caring and cooking. The UK Pentecostals also mentioned that, although women and men are equal in ministry, the submission of wives to their husbands was an accepted part of marriage. In the words of one UK Pentecostal, "I will just have to trust God and go with what my husband says". UK Pentecostal participants thus expressed limitations to gender equality within the family, in that 'the final say' lies with men. However, they also indicated that such limitations had to be accepted due to religious prescription, and thus privileged their religious faith and identities over concerns related to gender inequality. In other words, their lived religious citizenship accommodated certain gender inequalities. In 
contrast to UK Pentecostals, Norwegian Pentecostals did not problematize gender roles in the family, which could be linked to Norway overall being a more gender equal society than the UK (see Nyhagen Predelli and Halsaa 2012). Indeed, the interviewed Lutheran and Pentecostal women from Norway, and the Anglican women from the UK, did not talk much about gender relations within the family as a contentious issue within their religious communities. The Lutheran women approvingly noted developments in their church towards the ordination of women vicars (since 1961) and appointment of women bishops (since 1993). For them, there were no formal barriers to gender equality within the church. As one Lutheran participant noted, "I have never experienced that someone could not get a position due to their gender". Her experience and the rules of gender equal access to formal positions of religious authority within the Lutheran church, however, do not mean that there is full agreement among all sections of the church. According to some Lutheran interviewees, there are still people in the church who think that only men should be ordained as priests. However, such views were not portrayed as producing any real barriers to women's lived citizenship within the church, and Lutheran participants seemed to take for granted that equal gender rights trump dissonant views. The Anglican women's main focus was on the much-debated issue of leadership within the church. One Anglican participant noted, "when I first started, women couldn't even be ordained priests, so we have come on a long way from there". Interviewees recalled the issue of women priests as very controversial in some sections of the Church of England, with some people moving to the Roman Catholic Church. The question of women's leadership within the Church of England has also been debated in relation to the appointment of women bishops, 
which was only formally approved towards the end of 2014. One Anglican participant, herself a Lay reader, stated that “... if a woman can be a priest, I don't see why she can't be a bishop". She also noted, however, that women readers are not actually accepted everywhere, as one of her friends was prevented from becoming a reader by her local, male vicar. Another Anglican woman suggested that men who find it difficult to accept women in positions of religious authority “... try to find these little loopholes [in the Bible] saying that women aren't allowed to ...". She thought the Apostle Paul "was a bit of a male chauvinist pig really", and that Bible verses instructing women to sit still and be silent are not relevant to contemporary society. These reflections demonstrate that the interviewed Anglican women continue to face barriers to gender equality within church contexts and that they experience these barriers as problematic for their lived citizenship.

In general, Christian interviewees did not talk much about inclusion or exclusion in relation to the wider society. Among the few who did, some talked about the relationship between different faiths, and between religious and secular people. For example, one Christian interviewee suggested that her faith may be met with suspicion, and therefore she does not always reveal her faith to other people. Only two Christian interviewees (both Anglican) reflected on privileges attached to Christianity as the majority religion. One noted that Christians feel included in society simply because "we are supposed to be a Christian country", while the other stated that, "our society is actually set up in a way for Christianity, you don't think about it, you know". She suggested that it is easier to follow the Christian religion in the UK than any minority religions, "because everything is set up for 
you, people don't question it". These views thus indicated that religious

citizenship is not equal for people of all religions in the UK.

The interviewed Muslim women in both countries were very appreciative of their mosques, which offer women-only spaces via a separate entrance. This enables women to take part in religious services shared by both genders, where men are seated in the main prayer room and women in a separate room. The interviewees stated that women feel comfortable coming to the mosque because they have their own space, where they can talk about their personal lives as well as partake in religious prayers. Participants noted that some mosques do not have spaces for women, or only a small space for women's prayer, which were seen to produce barriers to women's participation. However, strict gender segregation, which is common practice in mosques in Europe and beyond, was not perceived to be a barrier to participation by the Muslim interviewees. Rather, gender segregation was seen as providing opportunities for women to participate in institutional religious life (see also Nyhagen Predelli 2008). By inhabiting their own gendered space in the mosque, Muslim women are thus 'altering the historically male-centered character of mosques' (Mahmood 2005, 2) whilst at the same time accepting the gendered practices dictated by religious tradition. Thus the more notable perhaps is the practice noted by a Shia Muslim in Norway, who said that the women's room in her mosque is so full of chatter that women who want to partake in the religious service have moved in to the main prayer room where men are seated. "So in our mosque they have introduced a system where you go [and] sit on the men's side. That is, women go and sit down in the men's section so that they can follow what is being said". This unusual practice further challenges the ordinary male-centeredness of mosques, as does the 
introduction of formal women's committees that have decision-making power in relation to women's activities and fundraising. For example, an interviewee from the UK Sunni mosque noted that, "ten years ago nobody would have thought of having a sub-committee of women who would have equal voting rights and look what we have achieved today". In this regard, religion can be viewed as a resource to increase Muslim women's participation and influence.

The Sunni and Shia interviewees in both countries also talked about the role of the Imam in the mosque, and they all imparted an acceptance of the existing norm that only men can inhabit this role. Without being prompted, several interviewees suggested that it would not be practical for women to be imams, because during the menstruating period "we are not pure, we are not allowed to pray", and hence women cannot lead prayers. The possibility of post-menopausal women leading prayer was not mentioned. While the interviewed women did not see any problems with women being prevented from leading gender-mixed prayers, one UK interviewee noted that she had heard of an event where a woman led such a prayer, ${ }^{3}$ thus signaling that the gender of the imam is becoming problematized at least in some contexts. However, neither she nor her mosque approves: "[...] God and the Prophet's rules were that the man should be performing and the men and women came behind to pray... God does not allow it, the priest does not allow it, so we won't debate about it". Allowing only men to be imams was not perceived as a hindrance to Muslim women's participation within the religious arena. The interviewed Muslim women's acceptance of gender inequalities within their religious organizations poses a challenge to rights-

\footnotetext{
${ }^{3}$ In 2008, American Professor Amina Wadud led a gender-mixed Muslim congregation in Oxford.
} 
based approaches to citizenship for which equal rights is a fundamental notion. The fact that religious women may choose to accommodate gender inequalities as part of their religious identities also challenges liberal feminist conceptions of gender equality as an ideal for citizenship practice.

The interviewed Muslim women (Shia and Sunni) also talked about women's role in the home and the labour market. They agreed that a woman's primary role is to take care of the home and children and support her husband, while a man's primary role is to provide for his family. This view accords with Islamic family law, which allocates to husbands the responsibility for "maintaining" their wives and to wives the duties of housework, child-rearing, and obedience to their husbands (Esposito 1982; see also Nyhagen Predelli 2004). Muslim participants saw women and men's complementary roles as of equal worth (rather than equal rights), and as "natural", stemming from men's physical strength and women's capacity for caring. It was also recognized by some, however, that modern life requires families to be supported by two wages, and that women therefore may have to work outside the home.

Muslim interviewees also talked about women and men having different rights, but saw this as a logical extension of their different natures and needs. For example, some participants noted that the court testimony from two women equals that of one man. This rule was seen as logical due to women being governed by emotions, while men were governed by reason. Furthermore, one participant suggested that women are better looked after in Islam than men, because women do not have to go out to work, and a woman's father and husband are responsible for providing for her. Instead, women can choose to work if they want to, or because of family needs, provided they have their 
husband's approval. Women are thus perceived as privileged, as they do not have any formal, financial obligations towards family. The allocation of unequal inheritance rights to women and men within Islam was also explained and justified within the same framework: men need more resources than women, as they are obliged to provide for others. The fact that women can keep their inheritance (albeit smaller than men's), meant to some interviewees that women have 'more rights' than men in Islam: "You can keep yours, nobody could force you to spend it on your family, but men can't keep it, they have to spend it on their family and their wife". More radically, a Shia participant suggested that a wife is permitted to charge her husband for breastfeeding, childcare housework, and sexual favours: "You could charge. No-where in the world, in no religions do you find all these points giving to the lady. You could charge your husband for anything you do. Even bedtime" (see Mir-Hosseini, 2000, 61-72, for a discussion of this view). Such transactional aspects of marriage may give women financial resources, particularly if they are not permitted to work outside the home. Nevertheless, the interviewed Muslim women's acceptance of women and men being accorded different formal rights within Islam poses particular challenges to rights-based approaches to citizenship.

Overall, Muslim participants perceived existing gender unequal norms and practices within their own religious community as unproblematic, and indeed as justified, thus indicating a difference between the views of Christian and Muslim interviewees. However, some Muslim participants referred to stereotypes in society at large as producing barriers to their lived citizenship. Due to negative media portrayals of Islam, and isolated terrorist incidents perpetrated by Muslims, some women felt they have to demonstrate that they are "a good 
Muslim", and that "good Muslims can be good citizens", so as to counter stereotypes. Participating and contributing to society were seen as values that should be promoted by Muslims in order to increase society's acceptance of Islam. One interviewee also suggested that Muslim women are under more pressure than Muslim men to demonstrate good citizenship, as women are more visibly Muslim due to their dress (e.g., hijab). Experiences of exclusion were also related to immigrant backgrounds, where some participants of foreign origin felt they were not always accepted as 'British' or 'Norwegian'.

\section{Conclusion}

The interviewed Christian and Muslim women in Norway and the UK forwarded a multidimensional understanding of citizenship, which echoes feminist approaches linking citizenship not only with status, rights and duties, but also with participation, identity and belonging (Lister 2003; Yuval-Davis 1999). Citizenship, they suggested, is linked to their sense of identity and belonging, as well as to their participation and engagement, in religious organisations, local neighbourhoods and wider communities. Moreover, interviewees linked citizenship to an ethics of tolerance, respect, love and care towards others; an ethical outlook which is rooted in religious conviction but transcends religious difference. These views and experiences pose a direct challenge to rights-based approaches to religious citizenship (e.g., Hudson 2003; Permoser and Rosenberger 2009) which tend to silence or neglect the importance of identities, participation, belonging and ethical imperatives about love and care. Rightsbased approaches to religious citizenship also overlook issues surrounding 
inequalities related to gender and to the majority/minority status of particular religions in specific social contexts.

Interviewees across both the Christian and Muslim faiths and the two countries identified strong connections between their own faith and citizenship, in that they saw their own religion as providing them with guidance on how to be a good citizen. It can thus be argued that 'lived religion' (McGuire, 2008) has a strong affinity with 'lived citizenship'. Some participants emphasized a commonality between all religious believers, in that all are equal before God, while others suggested that 'religious citizenship' should also be inclusive of non-believers. A few interviewees, however (most notably, but not exclusively, Muslims), viewed citizenship as mostly a secular matter concerning legal status. As such, they did not see citizenship as relevant to religion, and thought that religion is a matter above and beyond that of citizenship.

An acute problem with rights-based approaches to religious citizenship is when collective and group or individual rights collide. This can be illustrated via conflicts between the privileged rights of adherents of a state's official or dominant religion and the lesser rights of members of minority religions. Notably, none of the interviewees seemed to think of 'religious citizenship' in terms of the state allocating equal status and rights to different faiths. The question of the relationship between Christianity as the privileged majority religion and Islam and other religions as disadvantaged minority religions was largely left silent by the interviewees.

Conflicts between collective rights and group or individual rights may also arise in relation to gender discrimination, when patriarchal organisational rules override women's right to equality (Skjeie 2006). As this research shows, 
however, religious women do not always contest formal gender inequalities that are prescribed by religious traditions or imposed by religious leaders, and may also accept such inequalities as an inherent part of their own religious identities. As such, religious women's willing acceptance of formal gender inequalities pose a challenge to the idea that equal (religious) citizenship must be based on equal rights, whilst also supporting the move by feminist scholars to focus on identity, participation and belonging (and we may add an ethics of care) as important dimensions of citizenship as lived practice. Despite the noted connections between feminist scholars' conceptualizations and religious women's understandings of citizenship as identity, participation and belonging, however, a fundamental incompatibility exists between religious women's willingness to accept subordination and inferior rights in relation to men, and feminist notions of gender equality that forefront equal status and rights for women and men.

\section{References}

Ammerman, N. T., ed. 2007. Everyday Religion. Oxford: Oxford University Press. Anderson, A. 2004. An Introduction to Pentecostalism. Cambridge: Cambridge University Press.

Bäckström, A. and Davie, G. eds. 2010. Welfare and Religion in 21 ${ }^{\text {st }}$ Century

Europe: Volume 1. Farnham: Ashgate.

Bayes, J. and Tohidi, N. eds. 2001. Globalization, gender and religion. Basingstoke: Palgrave.

Beaman, L. G. 2013. The will to religion: Obligatory religious citizenship. Critical Research on Religion 1 (2), 141-157. 
Brochmann, G. 2002. Statsborgerskap, medborgerskap og tilhørighet, in G.

Brochmann, J. Rogstad, and T. Borchgrevink, eds. Sand i maskineriet. Oslo:

Gyldendal Akademisk, 56-84.

Casanova, J. 1994. Public religions in the modern world. Chicago: University of Chicago Press.

Davidman, L. 1991. Tradition in a Rootless World: Women turn to Orthodox Judaism. Berkeley: University of Calfornia Press.

Dillon, M. 2010. 2009 Association for the Sociology of Religion Presidential Address. Can Post-Secular Society Tolerate Religious Differences? Sociology of Religion 71 (2), 139-156.

Eisenberg, A. and Spinner-Halev, J. 2005. Minorities within minorities. Equality, rights and diversity. Cambridge: Cambridge University Press.

Esposito, J. L. 1998 Islam. The Straight Path. $3^{\text {rd }}$ ed. New York: Oxford University Press.

Fox, J. 2008 A world survey of religion and the state. Cambridge: Cambridge University Press.

Göle, N and Billaud, J. 2012. Islamic difference and the return of feminist universalism. In: A. Triandafyllidou, T. Modood and N. Meer, eds. European Multiculturalisms: Cultural, Religious and Ethnic Challenges. Edinburgh: Edinburgh University Press, 116-141.

Habermas, J. 2006. Religion in the public sphere. European Journal of Philosophy $14(1), 1-25$.

Hudson, W. 2003. Religious Citizenship. Australian Journal of Politics and History $49(3), 425-429$.

Isin, E. F. and Wood, P. K. 1999 Citizenship and Identity. London: Sage. 
Kilic, S. 2008. The British Veil Wars. Social Politics 15 (4), 433-454.

Kiwan, D. 2007. Citizenship education in England at the cross-roads? Four models of citizenship and their implications for ethnic and religious diversity. Oxford Review of Education 34 (1), 39-58.

Levitt, P. 2008. Religion as a path to civic engagement. Ethnic and Racial Studies $31(4), 766-791$.

Lister, R. 2003. Citizenship. Feminist Perspectives. $2^{\text {nd }}$ ed. New York: Palgrave Macmillan.

Lister, R., Williams, F., Anttonen, A., Bussemaker, J., Gerhard, U., Heinen, J., Johansson, S., Leira, A., Siim, B. and Tobio, C. with Gavanas, A. 2007. Gendering Citizenship in Western Europe. New challenges for citizenship research in a crossnational context. Bristol: Policy Press.

Loenen M. L. P. and Goldsmith J. E. eds., 2007. Religious Pluralism and Human Rights in Europe: Where to Draw the Line? Antwerpen: Intersentia.

Mahmood, S. 2005. Politics of Piety: The Islamic Revival and the Feminist Subject. Princeton: Princeton University Press.

McGuire, M. B. 2008. Lived Religion: Faith and Practice in Everyday Life. Oxford: Oxford University Press.

Mir-Hosseini, Z. 2000. Islam and Gender. The Religious Debate in Contemporary Iran. London: I.B. Tauris.

Nyhagen Predelli, L. and Halsaa, B. 2012. Majority-Minority Relations in Contemporary Women's Movements: Strategic Sisterhood. Basingstoke: Palgrave Macmillan.

Nyhagen Predelli, L., Halsaa B., Manful E., Thun C. and Quintero E. 2010. Christian and Muslim Women in Norway, Spain and the United Kingdom: A Qualitative Study 
of Religion, Gender and Citizenship. FEMCIT WP 4, Working Paper No. 10.

Department of Social Sciences and Centre for Research in Social Policy, Loughborough University, and Centre for Gender Research, University of Oslo. Nyhagen Predelli, L. 2008. Religion, Citizenship and Participation: A Case Study of Immigrant Muslim Women in Norwegian Mosques. European Journal of Women's Studies 15 (3), 241-260.

Nyhagen Predelli, L. 2004. Interpreting Gender in Islam: A Case Study of Immigrant Muslim Women in Oslo, Norway. Gender \& Society 18 (4), 473-493.

Okin, S. M. 1999. Is Multiculturalism Bad for Women? Princeton: Princeton University Press.

Permoser, J. M. and Rosenberger, S. 2009. Religious citizenship as a substitute for immigrant integration? The governance of diversity in Austria. In: E. Guild, K. Groenendijk and S. Carrera, eds. Illiberal Liberal States. Aldershot: Ashgate, 149166.

Phillips, A. 2010. Gender \& Culture. Cambridge: Polity Press.

Rosenblum, N. L. 2000. Obligations of Citizenship and Demands of Faith.

Princeton: Princeton University Press.

Ryder, B. 2008. The Canadian Conception of Equal Religious Citizenship. In: R. Moon, ed. Law and Religious Pluralism in Canada. Vancouver: University of British Columbia Press.

Skjeie, H. 2006. Gender equality: On travel metaphors and duties to yield. In: S. K. Hellsten, A. M. Holli and Daskalova, K., eds. Women's Citizenship and Political Rights. New York: Palgrave Macmillan.

Spinner-Halev, J. 2000. Surviving Diversity: Religion and Democratic Citizenship. Baltimore: The Johns Hopkins University Press. 
Sunstein, C. R. 1999. Should sex equality law apply to religious institutions? In: J.

Cohen, M. H. and Nussbaum, M. C., eds. Is Multiculturalism Bad for Women?

Princeton: Princeton University Press, 85-94.

Tronto, J. 2005. Care as the work of citizens: A modest proposal. In: M. Friedman, ed. Women and Citizenship. Oxford: Oxford University Press, 130-145.

Turner, B. S. 2012. Managing religions, citizenship and the liberal paradox. Citizenship Studies 16 (8), 1059-1072.

Van den Brink, M. 2007. Equals in Faith - Faith in Equality. In: M. L. P. Loenen and J. E. Goldsmith, eds. Religious Pluralism and Human Rights in Europe: Where to Draw the Line? Antwerpen: Intersentia, 211-218.

Weithman, P. J. 2002. Religion and the Obligations of Citizenship. Cambridge: Cambridge University Press.

Yip, A. K. T. 2003. Sexuality and the Church. Sexualities 6 (1), 60-64.

Yuval-Davis, N. 1999. The 'Multi-Layered Citizen'. International Feminist Journal of Politics 1 (1), 119-136.

Yuval-Davis, N. 2006. Belonging and the politics of belonging. Patterns of Prejudice 40 (3), 197-214. 